\title{
ANTIBACTERIAL ACTIVITY OF ROXITHROMYCIN: A LABORATORY EVALUATION
}

\author{
Jean-François Chantot*, André Bryskier and Jean-Claude Gasc \\ Centre de Recherches Roussel-Uclaf, \\ 104, Route de Noisy, 93230-Romainville, France
}

(Received for publication October 1, 1985)

\begin{abstract}
Roxithromycin, formerly known as RU 28965 (9-[O[(2-methoxyethoxy)methyl]oxime]erythromycin), is a novel 14 atom-membered semisynthetic macrolide with an antibacterial spectrum directed towards Gram-positive cocci and bacilli, Gram-negative cocci and some Parvobacteriaceae. The in vitro antibacterial activity of roxithromycin was compared with those of erythromycin and spiramycin against 275 clinical isolates by using 2 -fold broth macro-dilution tests. The antibacterial spectrum of roxithromycin and erythromycin were qualitatively comparable (including the bacteriostatic type of activity and the profile of resistance), but minimal inhibitory concentrations of erythromycin were generally one half those of roxithromycin, except for Corynebacterium sp. and Bacteroides fragilis against which the new macrolide was more active. On the other hand, roxithromycin exhibited a superior in vivo antibacterial activity in laboratory animals, being up to six times more potent than erythromycin in curing experimentally infected mice. Roxithromycin showed high blood levels and long half-lives of elimination in rodents after oral administration, and its bioavailability amounted to $72 \%$ in mice and $85 \%$ in rats, compared to less than $10 \%$ for erythromycin. Roxithromycin was widely distributed throughout the body with a high degree of penetration into all tissues, particularly in the lungs.
\end{abstract}

Since the discovery of erythromycin by McGuirE ${ }^{1)}$ in 1952, several other macrolides have been isolated from various species of Streptomyces during the last decade. Oleandomycin ${ }^{2)}$, spiramycin ${ }^{3)}$ and josamycin ${ }^{4)}$, however, did not meet with the same success as erythromycin which has been extensively used for years all over the world.

Macrolides are antimicrobial agents with activity essentially directed towards Gram-positive bacteria $^{5)}$. A major indication of macrolides lies in the therapy of respiratory tract infections caused by Gram-positive pathogens where it is used as an alternative to penicillins in not severely-ill outpatients or as a second-line agent for the treatment of penicillin-hypersensitive in-patients. More recently, macrolides have become the drugs of choice in the therapy of atypical pneumonia due to Legionella pneumophila, Mycoplasma pneumoniae or Chlamydia. Another useful indication of erythromycin is in the field of sexually transmitted diseases where it proves to be very efficient for the treatment of non-gonococcal urethritis due to Ureaplasma urealyticum and Chlamydia trachomatis.

Erythromycin is an orally administered antibiotic which breaks down in the acid conditions of the stomach. Hence, there is a limited and irregular enteral absorption of the drug which accounts for unsatisfactory pharmacokinetics and has to be counter-balanced by very high daily dosages.

Roxithromycin is a new semisynthetic macrolide in which the 14 atom-membered macrocyclic lactone has been locally modified to prevent inactivation in gastric medium ${ }^{6)}$. First reports on the in vitro antibacterial activity of roxithromycin have shown that new macrolide retains the same antibacterial spectrum as that of erythromycin on common pathogens ${ }^{6 \sim 8)}$. This paper details the in vitro antibacterial properties of roxithromycin (Fig. 1) in comparison with erythromycin and spiramycin. In addition, a murine septicemia model has been used to assess the in vivo therapeutic efficiency of 
Fig. 1. Structure of roxithromycin (RU 28965).

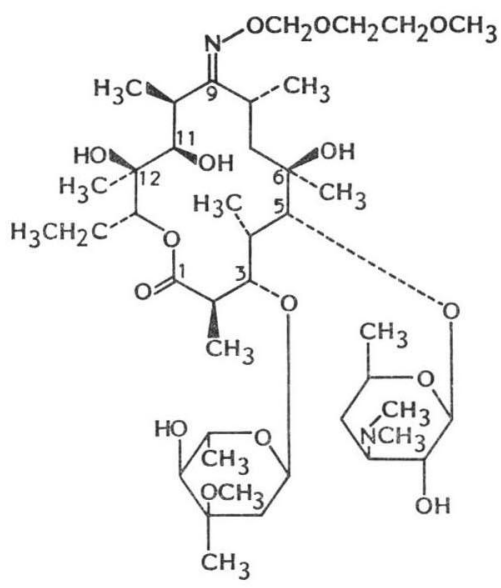

the drug in experimental infections caused by Gram-positive pathogens. Finally, we have compared the pharmacokinetic profiles of erythromycin and roxithromycin and determined the distribution of both compounds in several tissues of laboratory animals.

\section{Material and Methods}

Antibiotics

The following antibiotics have been used; roxithromycin, erythromycin (Roussel-UCLAF) and spiramycin (Rhône-Poulenc). For in vitro tests, stock solutions were prepared by dissolving the antibiotics first in DMSO (10\%) and making up with $0.1 \mathrm{M}$ phosphate buffer, $\mathrm{pH} 8$ (the DMSO concentration never exceeded $0.4 \%$ in the actual

assay of antibacterial activity). Antibiotics were suspended in $0.25 \%$ carboxymethylcellulose $-0.20 \%$ Tween 80 for oral administration to mice and rats. For subcutaneous injection of drugs, the macrolides were first suspended in $1.0 \mathrm{ml}$ of distilled water, dissolved with the addition of the required amount of pure acetic acid and the solution was made up with $0.1 \mathrm{M}$ phosphate buffer-saline.

\section{Bacterial Strains}

About 275 strains have been used in this study. Most of them were recent clinical isolates obtained from several French and German hospitals.

\section{Determination of Minimum Inhibitory Concentrations (MIC)}

Antibacterial susceptibility tests were carried out by using broth dilution techniques. Different mediums were used: Mueller-Hinton broth (Institut Pasteur Production), pH 7.4, for Staphylococci and Enterobacteriaceae; Todd-Hewitt broth (Difco), $\mathrm{pH}$ 8, for Streptococci; Tryptone soya broth (Oxoid), pH 7.3, supplemented with hemin and yeast extract for Haemophilus, or with $10 \%$ human serum for Moraxella; TGY broth (Institut Pasteur Production), pH 7.4, supplemented with hemin for anaerobes. Neisseria gonorrhoeae was grown in Tryptone soya broth with $10 \%$ supplement G (Institut Pasteur Production). Liquid macro-dilution tests were performed in tubes containing 2-fold dilutions of the test compound in $5.0 \mathrm{ml}$ medium. Inocula were prepared by prediluting $(1 / 200)$ an overnight bacterial culture yielding viable counts at about $10^{9}$ colony-forming units (cfu) per $\mathrm{ml}$. Test tubes were seeded at a final standard inoculum of about $10^{5} \mathrm{cfu} / \mathrm{ml}$. The effect of inoculum size on MICs was determined by using the standard inoculum with 100 -fold lower and higher bacterial cell concentrations. Tubes were incubated at $36^{\circ} \mathrm{C}$ for 20 hours. Incubation was performed in Gas Pack jars (BioMerieux) for anaerobes. $10 \% \mathrm{CO}_{2}$ was present in the jars to support the growth of Haemophilus and N. gonorrhoeae. MIC was defined as the lowest concentration at which no visible growth could be detected in tubes.

\section{Determination of Minimum Bactericidal Concentrations (MBC)}

MBCs were determined by transferring $0.01 \mathrm{ml}$ from clear tubes onto drug-free Mueller-Hinton agar (Institut Pasteur Production) and incubating for a further 24 hours at $36^{\circ} \mathrm{C}$. The $\mathrm{MBC}$ corresponded to the lowest concentration resulting in a $99.9 \%$ kill, i.e. not more than a single colony after subculture.

\section{In Vivo Therapeutic Activity}

Male Charles-River $\mathrm{CD}_{1}$ mice were used to study the antibacterial activity of the drugs in murine systemic infections. Each dosing group was composed of ten individuals weighing 20 to $22 \mathrm{~g}$. Mice were infected intraperitoneally with $0.5 \mathrm{ml}$ of an overnight broth culture of bacteria appropriately 
diluted in physiological saline or in $5 \%$ hog gastric mucine (Sigma) to a final cell density corresponding to $10 \sim 100$ times the minimal lethal dose $(\mathrm{MLD})^{9)}$. Suspensions of the compounds $(0.5 \mathrm{ml})$ were administrated by the oral route, 1,5 and 24 hours post infection. Mice were observed for 8 to 10 days following infection and the $50 \%$ protection dose $\left(\mathrm{PD}_{50}\right)$, expressed as the sum of the three doses required to protect $50 \%$ of the animals from death, was calculated according to standard procedures ${ }^{\vartheta}$.

Determination of Antibiotic Blood Levels

Mice: $20 \mathrm{mg} / \mathrm{kg}$ of roxithromycin or erythromycin was given orally or injected subcutaneously to groups of five Charles-River $\mathrm{CD}_{1}$ Swiss albino mice weighing $35 \mathrm{~g}$. $0.15,0.5,0.75,1,1.5,2,3,4,5,6$ and 7 hours after administration, $20 \mu \mathrm{l}$ samples of blood were removed from each individual from a cut on the tip of the tail by using a Gilson micropipette fitted with heparazined disposable tips (Gilson). The five blood samples were immediatly assayed on the same plate.

Rats: The technique was essentially the same as that used for mice. Groups of five Iffa-Credo Sprague Dawley rats weighing $140 \mathrm{~g}$ were used instead. An additional sampling time was set up 15 hours after administration of roxithromycin.

Tissue Levels

Groups of four mice or rats were killed 1 or 2 hours after oral dosing with $20 \mathrm{mg} / \mathrm{kg}$ of roxithromycin or erythromycin. Small pieces of organs were dried under vacuum for 2 days and then finely ground in a mortar. Dry powders were extracted three times with methanol. The extracts were combined and the organic solvent was evaporated by flushing with nitrogen. Residues were solubilized back in $0.1 \mathrm{M}$ phosphate buffer, $\mathrm{pH} 8$, and assayed for antibiotic contents.

\section{Protein Binding}

The protein binding of macrolides to mouse or rat serum (at $2.5 \mu \mathrm{g} / \mathrm{ml}$ ) and to human serum (at $10 \mu \mathrm{g} / \mathrm{ml}$ ) was determined by an ultracentrifugation technique ${ }^{9)}$ which used CF50A Centriflo membrane ultrafiltration cones (Amicon Corporation).

Microbiological Assay

Concentrations of antibiotics were determined by an agar diffusion method with Antibiotic Medium 11 (Difco) as the culture medium. Micrococcus luteus IP5345 was used as the indicator organism. The final inoculum in agar was adjusted to $10^{7}$ microorganisms per $\mathrm{ml}$ by appropriately diluting concentrated test organism suspensions kept in frozen vials. $20 \mathrm{ml}$ of seeded molten agar $\left(50^{\circ} \mathrm{C}\right)$ was poured into $12 \times 12 \mathrm{~cm}$ Petri dishes (Greiner). After hardening, 16 wells, $4 \mathrm{~mm}$ in diameter, were cut in agar. Each plate received 5 samples corresponding to the same sampling time if blood levels were to be measured. The other wells were filled with standard solutions of the test compound prepared in mouse or rat blood. When measuring tissue levels or protein binding, standard solutions were prepared in $0.1 \mathrm{M}$ phosphate buffer, $\mathrm{pH} 8$. The detection limit was approximately $0.1 \mu \mathrm{g} / \mathrm{ml}$.

\section{Results}

\section{In Vitro Antibacterial Activity}

Table 1 summarizes the in vitro antibacterial activity of roxithromycin in comparison with erythromycin and spiramycin. Roxithromycin has about one-half the activity of erythromycin against Staphylococcus, $50 \%$ of the strains being inhibited at 0.6 and $0.3 \mu \mathrm{g} / \mathrm{ml}$, respectively. Methicillinresistant strains of Staphylococcus were usually resistant to all macrolides. Staphylococcal isolates resistant to erythromycin were also resistant to roxithromycin, thus demonstrating close cross-resistance between the two compounds.

Against Streptococci from group D, which mainly included Enterococcus faecalis isolates and a few strains of E. faecium, erythromycin showed the highest activity. $\mathrm{MIC}_{50}$ and $\mathrm{MIC}_{90}$ for roxithromycin were 1.2 and $5 \mu \mathrm{g} / \mathrm{ml}$, respectively. Roxithromycin was inactive against erythromycin-resistant strains. Groups A, B and C Streptococci were very susceptible to the new macrolide which inhibited 
Table 1. Comparative in vitro antibacterial activity of erythromycin, spiramycin and roxithromycin.

\begin{tabular}{|c|c|c|c|c|}
\hline \multirow{2}{*}{ Organisms (No. of strains) } & \multirow{2}{*}{ Drug } & \multicolumn{3}{|c|}{$\operatorname{MIC}(\mu \mathrm{g} / \mathrm{ml})$} \\
\hline & & Range & $50 \%$ & $90 \%$ \\
\hline Staphylococcus sp. (69) & Roxithromycin & $0.3 \sim 2.5$ & 0.6 & 1.2 \\
\hline \multirow[t]{2}{*}{ Erythromycin susceptible } & Erythromycin & $0.15 \sim 1.2$ & 0.3 & 0.6 \\
\hline & Spiramycin & $0.6 \sim 10$ & 2.5 & 5 \\
\hline Staphylococcus sp. (28) & Roxithromycin & $20 \sim>40$ & $>40$ & $>40$ \\
\hline \multirow[t]{2}{*}{ Erythromycin resistant } & Erythromycin & $10 \sim>40$ & $>40$ & $>40$ \\
\hline & Spiramycin & $20 \sim>40$ & $>40$ & $>40$ \\
\hline Streptococcus sp. (42) & Roxithromycin & $0.15 \sim 5$ & 1.2 & 5 \\
\hline Group D & Erythromycin & $0.08 \sim 1.2$ & 0.3 & 1.2 \\
\hline Erythromycin susceptible & Spiramycin & $0.3 \sim 1.2$ & 0.6 & 1.2 \\
\hline Streptococcus sp. (16) & Roxithromycin & $>40$ & $>40$ & $>40$ \\
\hline Group D & Erythromycin & $>40$ & $>40$ & $>40$ \\
\hline Erythromycin resistant & Spiramycin & $>40$ & $>40$ & $>40$ \\
\hline Streptococcus sp. (13) & Roxithromycin & $0.02 \sim 0.04$ & 0.04 & 0.04 \\
\hline \multirow{2}{*}{ Groups A, B and C } & Erythromycin & $0.01 \sim 0.04$ & 0.02 & 0.02 \\
\hline & Spiramycin & $0.15 \sim 2.5$ & 0.15 & 0.3 \\
\hline Streptococcus sp. (4) & Roxithromycin & $0.005 \sim 0.04$ & $(0.02)$ & $(0.04)$ \\
\hline \multirow[t]{2}{*}{ Groups E, F, G and $\mathrm{H}$} & Erythromycin & $0.005 \sim 0.02$ & $(0.01)$ & $(0.02)$ \\
\hline & Spiramycin & $0.15 \sim 0.3$ & $(0.1)$ & $(0.3)$ \\
\hline Streptococcus sp. (4) & Roxithromycin & $2 \sim 10$ & (10) & (10) \\
\hline \multirow[t]{2}{*}{ Groups $\mathrm{K}, \mathrm{L}, \mathrm{M}$ and $\mathrm{N}$} & Erythromycin & $1.2 \sim 2.5$ & $(2.5)$ & $(2.5)$ \\
\hline & Spiramycin & $0.6 \sim 2.5$ & $(2.5)$ & $(2.5)$ \\
\hline Streptococcus sp. (8) & Roxithromycin & $0.04 \sim 0.15$ & 0.04 & 0.15 \\
\hline \multirow[t]{2}{*}{ Non groupable } & Erythromycin & $0.005 \sim 0.08$ & 0.01 & 0.08 \\
\hline & Spiramycin & $0.04 \sim 0.15$ & 0.04 & 0.15 \\
\hline \multirow[t]{3}{*}{ S. pneumoniae (10) } & Roxithromycin & $0.005 \sim 0.02$ & 0.01 & 0.02 \\
\hline & Erythromycin & $0.002 \sim 0.01$ & 0.005 & 0.01 \\
\hline & Spiramycin & $0.01 \sim 0.15$ & 0.02 & 0.08 \\
\hline \multirow[t]{3}{*}{ Corynebacterium sp. (12) } & Roxithromycin & $0.02 \sim 0.04$ & 0.02 & 0.02 \\
\hline & Erythromycin & $0.01 \sim 0.04$ & 0.04 & 0.04 \\
\hline & Spiramycin & $0.15 \sim 0.6$ & 0.3 & 0.6 \\
\hline \multirow[t]{3}{*}{ Moraxella sp. (10) } & Roxithromycin & $0.25 \sim 2.5$ & 1.2 & 2.5 \\
\hline & Erythromycin & $0.08 \sim 2.5$ & 0.6 & 1.2 \\
\hline & Spiramycin & $0.6 \sim>40$ & 2.5 & 20 \\
\hline \multirow[t]{3}{*}{ Haemophilus sp. (12) } & Roxithromycin & $0.6 \sim 5$ & 2.5 & 5 \\
\hline & Erythromycin & $0.6 \sim 2.5$ & 1.2 & 2.5 \\
\hline & Spiramycin & - & - & - \\
\hline \multirow[t]{3}{*}{ Neisseria gonorrhoeae (4) } & Roxithromycin & $0.3 \sim 2.5$ & $(1.2)$ & $(2.5)$ \\
\hline & Erythromycin & $0.3 \sim 1.2$ & $(0.6)$ & $(1.2)$ \\
\hline & Spiramycin & - & - & - \\
\hline \multirow[t]{3}{*}{ Escherichia coli (17) } & Roxithromycin & $40 \sim>40$ & $>40$ & $>40$ \\
\hline & Erythromycin & $20 \sim>40$ & $>40$ & $>40$ \\
\hline & Spiramycin & $>40$ & $>40$ & $>40$ \\
\hline \multirow[t]{3}{*}{ Klebsiella pneumoniae (15) } & Roxithromycin & $>40$ & $>40$ & $>40$ \\
\hline & Erythromycin & $>40$ & $>40$ & $>40$ \\
\hline & Spiramycin & $>40$ & $>40$ & $>40$ \\
\hline \multirow{3}{*}{$\begin{array}{l}\text { Bacteroides sp. (11) } \\
\text { including } 9 \text { B. fragilis }\end{array}$} & Roxithromycin & $0.15 \sim>20$ & 0.6 & $>20$ \\
\hline & Erythromycin & $0.6 \sim>20$ & 1.2 & $>20$ \\
\hline & Spiramycin & - & - & - \\
\hline
\end{tabular}


Table 2. Effect of the inoculum size on the antibacterial activity of erythromycin and roxithromycin.

\begin{tabular}{|c|c|c|c|c|c|}
\hline & \multirow{3}{*}{$\begin{array}{l}\text { Inoculum } \\
(\mathrm{cfu} / \mathrm{ml})\end{array}$} & \multicolumn{4}{|c|}{ Geometric mean of MIC and MBC $(\mu \mathrm{g} / \mathrm{ml})$} \\
\hline & & \multicolumn{2}{|c|}{ Erythromycin } & \multicolumn{2}{|c|}{ Roxithromycin } \\
\hline & & MIC & $\mathrm{MBC}$ & MIC & $\mathrm{MBC}$ \\
\hline \multirow{3}{*}{$\begin{array}{l}\text { Staphylococcus aureus } \\
\text { (5 strains) }\end{array}$} & $10^{3}$ & 0.06 & 0.18 & 0.08 & 0.6 \\
\hline & $10^{5}$ & 0.1 & 2.5 & 0.2 & 2.5 \\
\hline & $10^{7}$ & 0.35 & 3.6 & 0.8 & 5.9 \\
\hline \multirow{3}{*}{$\begin{array}{l}\text { Streptococcus sp. } \\
\text { (5 strains) }\end{array}$} & $10^{3}$ & 0.26 & 0.7 & 0.79 & 8.7 \\
\hline & $10^{5}$ & 0.52 & 7 & 1.2 & 25 \\
\hline & $10^{7}$ & 1.2 & 13.2 & 2.8 & 45 \\
\hline
\end{tabular}

$90 \%$ isolates at less than $0.1 \mu \mathrm{g} / \mathrm{ml}$. Although the number of strains used to ascertain the results was low (one strain from each group), Streptococci from groups E, F, G and H seemed to show a trend of greater susceptibility to all macrolides than did Streptococci from groups, K, L, M and N. Roxithromycin was highly active against non-groupable Streptococci, such as Streptococcus sanguis and S. mitis. S. pneumoniae was very susceptible to erythromycin and roxithromycin which inhibited all strains at $0.02 \mu \mathrm{g} / \mathrm{ml}$.

Roxithromycin was more active than erythromycin against Corynebacterium $\left(\mathrm{MIC}_{00}\right.$ of $0.02 \mu \mathrm{g} /$ $\mathrm{ml}$ ) but was less potent against Haemophilus, N. gonorrhoeae and Moraxella. As expected with Enterobacteriaceae, all compounds were inactive against Escherichia coli and Klebsiella pneumoniae. Roxithromycin was reasonably active against anaerobic bacilli such as Bacteroides and resistant strains to both macrolides amounted to $20 \%$.

The effect of increasing inoculum density upon MICs and MBCs for Staphylococci and Streptococci (five strains each) is shown in Table 2. Roxithromycin and erythromycin exhibited a 4 to 10fold increase in MICs when the inoculum was increased from $10^{3}$ to $10^{7} \mathrm{cfu} / \mathrm{ml}$. Similar findings were demonstrated with MBCs.

\section{In Vivo Antibacterial Activity}

Table 3 gives the protective dose of erythromycin and roxithromycin obtained for several systemic infections in the mouse. The in vivo therapeutic activity of roxithromycin was found to be three to six times higher than that of erythromycin, irrespective of a lower in vitro activity, in many instances, against the infecting microorganisms.

\section{Pharmacokinetic Studies}

Roxithromycin and erythromycin blood levels in mice and rats after a single subcutaneous or oral administration at $20 \mathrm{mg} / \mathrm{kg}$ are shown in Figs. 2 and 3. In mice, peak blood levels at $2.15 \mu \mathrm{g} / \mathrm{ml}$ (subcutaneous) and $1.5 \mu \mathrm{g} / \mathrm{ml}$ (oral) were reached 1 hour after administration of roxithromycin. The elimination half-life of the drug was 80 minutes. In rats, the corresponding value amounted to 3.5 hours and traces of the compounds were still detectable after 15 hours. Erythromycin could hardly be detected in the blood of both rodent species after oral administration. There was a rapid elimination of the drug after subcutaneous dosing, with corresponding half-lives of 40 and 50 minutes in mice and rats, respectively. The relative bioavailability of roxithromycin could be worked out from these curves. It amounted to $72 \%$ in mice and $85 \%$ in rats, compared to less than $10 \%$ for erythromycin.

Table 4 summarizes the antibiotic concentrations obtained in several tissues of mice and rats. 
Table 3. Comparative in vivo antibacterial activity of erythromycin and roxithromycin.

\begin{tabular}{|c|c|c|c|c|}
\hline \multirow{2}{*}{ Infecting strain } & \multirow{2}{*}{ Drug } & \multirow{2}{*}{$\begin{array}{c}\mathrm{MIC} \\
(\mu \mathrm{g} / \mathrm{ml})\end{array}$} & \multirow{2}{*}{$\begin{array}{c}\mathrm{PD}_{50} \\
(\mathrm{mg} / \mathrm{kg})\end{array}$} & \multirow{2}{*}{$\begin{array}{l}\mathrm{PD}_{50} \text { Erythromycin } \\
\mathrm{PD}_{50} \text { Roxithromycin }\end{array}$} \\
\hline & & & & \\
\hline Staphylococcus aureus & Erythromycin & 0.3 & 120 & 3.2 \\
\hline 54146 & Roxithromycin & 0.6 & 37 & \\
\hline S. aureus & Erythromycin & 0.15 & 60 & 2.6 \\
\hline Giorgio & Roxithromycin & 0.3 & 23 & \\
\hline Streptococcus pyogenes A & Erythromycin & 0.0025 & 225 & 2.3 \\
\hline A561 & Roxithromycin & 0.0025 & 98 & \\
\hline S. pyogenes A & Erythromycin & 0.0025 & 150 & 2.6 \\
\hline A77-5507 & Roxithromycin & 0.005 & 57 & \\
\hline \multirow[t]{2}{*}{ S. aronson B } & Erythromycin & 0.02 & 260 & 3.1 \\
\hline & Roxithromycin & 0.02 & 84 & \\
\hline S. agalactiae B & Erythromycin & 0.02 & 87 & 2.3 \\
\hline Q698 & Roxithromycin & 0.04 & 37 & \\
\hline S. pneumoniae I & Erythromycin & 0.02 & 375 & 5.6 \\
\hline $69-2$ & Roxithromycin & 0.04 & 67 & \\
\hline Pneumococcus mucosus & Erythromycin & 0.02 & 69 & 3 \\
\hline Q1454 & Roxithromycin & 0.04 & 23 & \\
\hline Listeria monocytogenes & Erythromycin & 0.08 & 100 & 3.7 \\
\hline IGR Orlandi & Roxithromycin & 0.15 & 27 & \\
\hline
\end{tabular}

Fig. 2. Erythromycin and roxithromycin blood levels in mice after a single subcutaneous or oral administration of $20 \mathrm{mg} / \mathrm{kg}$.

Subcutaneous: Roxithromycin ( ), erythromycin (○). Oral: Roxithromycin ( $)$, erythromycin ( $\square$ ).

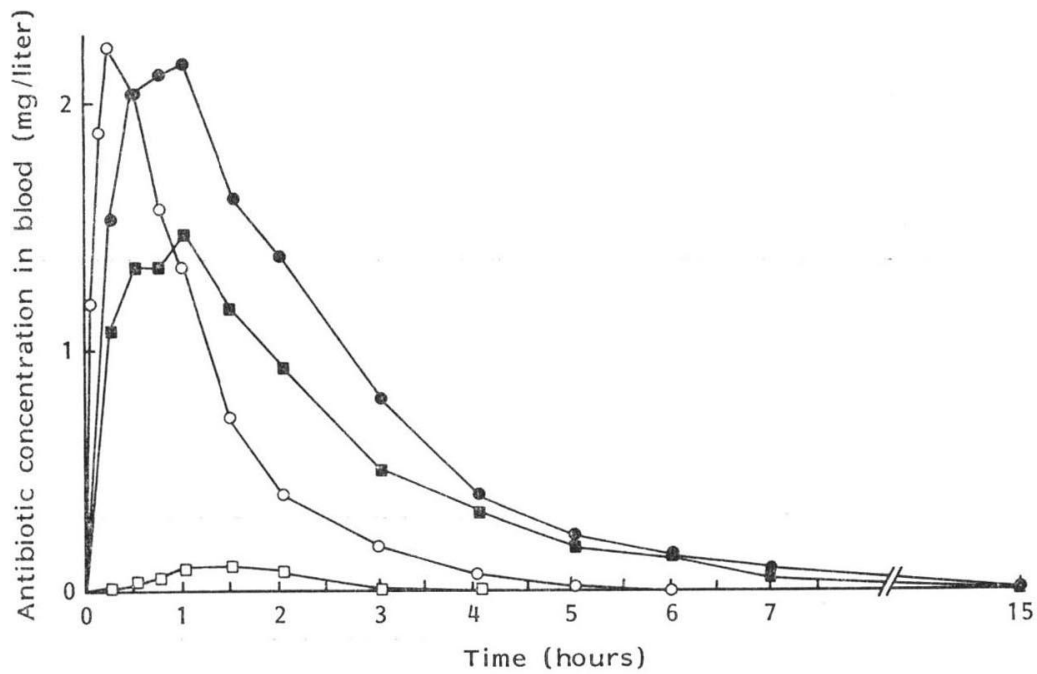

Roxithromycin is widely distributed throughout the body with tissue levels well above the serum concentration, particularly in the lungs where it is five to ten times more concentrated. Erythromycin exhibits the same tendency to build up higher concentrations in tissues, but to an extent which it is difficult to estimate correctly because the detection of the drug is limited in the assay used at present. Also, tissue levels of erythromycin are significantly lower.

Table 5 shows that both compounds exhibit a high affinity for serum proteins of all animal species. Roxithromycin is more highly bound, however, to serum proteins than is erythromycin, especially in human serum. 
Fig. 3. Erythromycin and roxithromycin blood levels in rats after a single subcutaneous or oral administration of $20 \mathrm{mg} / \mathrm{kg}$.

Subcutaneous: Roxithromycin (๑), erythromycin (○). Oral: Roxithromycin ( $\mathbf{\square})$, erythromycin ( $\square$ ).

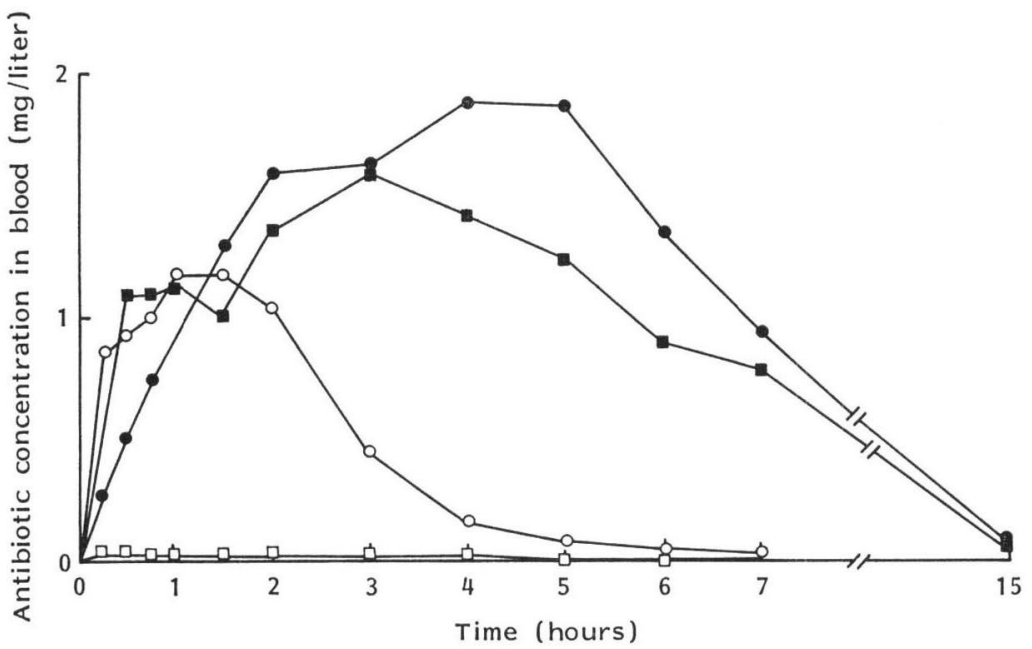

Table 4. Serum and tissue levels of erythromycin and roxithromycin, 1 hour (mice) or 2 hours (rats) after a single oral administration of $20 \mathrm{mg} / \mathrm{kg}$.

\begin{tabular}{lrrrrrr}
\hline & Serum & Heart & Lung & Liver & Kidney & Muscle \\
\cline { 2 - 7 } & \multicolumn{5}{c}{$(\mu \mathrm{g} / \mathrm{g}$ dry tissue $)$} \\
\hline Roxithromycin & & & & \\
$\quad$ Mouse & 6.1 & 9.8 & 31.0 & 27.9 & 14.6 & 6.2 \\
$\quad$ Rat & 3.1 & 6.1 & 39.4 & 7.5 & 7.7 & 2.5 \\
Erythromycin & & & & & \\
$\quad$ Mouse & $<1.3$ & $<2.7$ & $<2.2$ & 4.2 & 1.5 & 0.9 \\
Rat & $<0.4$ & $<1.9$ & 2.0 & $<0.5$ & 2.3 & $<0.6$ \\
\hline
\end{tabular}

\section{Discussion}

The antibacterial spectrum of roxithromycin is typically that of a 14 atom-membered lactone macrolide. Its in vitro activity is similar to that of erythromycin, being mainly directed towards Gram-positive cocci and bacilli, Gram-negative cocci and some Parvobacteriaceae. A general trend towards greater macrolide susceptibility has been noted by others among Staphylococcus isolates producing penicillinase compared with penicillin-susceptible strains ${ }^{7)}$. Like erythromycin, roxithromycin has been found to be effective against less commonly encountered pathogens such as Listeria ${ }^{8,10)}$, Branhamella catarrhalis $^{8,10)}$ and Campylobacter ${ }^{10)}$. In addition, the new macrolide is endowed with excellent activity against Legionella ${ }^{8,11)}$ (including L. pneumophila), M. pneumoniae ${ }^{12)}$, Ureaplasma urealyticum $^{13)}$, superior to that of the reference compound. $M$. hominis is only marginally susceptible to both erythromycin and roxithromycin ${ }^{12)}$. Against $C$. trachomati $^{14,15)}$, roxithromycin proved to be superior to tetracycline, which is the preferred drug for the treatment of infections caused by these particular microorganisms.

As far as bacterial resistance is concerned, many bacterial species, if not all, demonstrate close
Table 5. Binding of erythromycin and roxithromycin to serum proteins.

\begin{tabular}{lcc}
\hline & \multicolumn{2}{c}{ Binding ratio (\%) } \\
\cline { 2 - 3 } & Roxithromycin & Erythromycin \\
\hline Mouse & 93.6 & 84.6 \\
Rat & 91.4 & 83.6 \\
Human & 95 & 80 \\
\hline
\end{tabular}


cross-resistance to erythromycin and roxithromycin. The activity of the new macrolide appears to be predominantly bacteriostatic with the exception of Chlamydia ${ }^{14)}$ where it is largely bactericidal.

Roxithromycin exhibits an outstanding in vivo therapeutic efficacy in experimentally infected mice. Indeed, the chemical modification of the keto group in the 9-position of the lactone macrocycle prevents the drug from being inactivated by internal ketalization in gastric medium ${ }^{6}$. Hence, the ratio of active compound available at the site of intestinal resorption is high, thus leading to improved in vivo efficiency in comparison with erythromycin.

The effective passage of roxithromycin across the gastro-intestinal barrier was confirmed by pharmacokinetic studies in laboratory animals. After oral administration of the drug, high blood levels and large area under the concentration-time curves are obtained in rats and mice. By comparing with an identical subcutaneous dosing of the compound, the rate of absorption was found to be almost quantitative in some individuals, in contrast to the poor bioavailability of erythromycin. Elimination of roxithromycin proceeds through an exceptionally long half-life and effective levels of the antibiotic are still present in the blood compartment several hours after oral administration. Prolonged blood levels can be related in part to the high ratio of binding to serum proteins. Similar favourable pharmacokinetic properties have been obtained in other animal species. ${ }^{\left.1{ }^{1}\right)}$

Roxithromycin shows excellent penetration from the blood stream into various tissues of laboratory animals, particularly in the lungs where the level of the antibiotic culminates at a value five (mouse) to ten (rat) times above that recorded in serum. This is a favorable situation for treating lung infections which are indeed a prime target for macrolide therapy.

It has previously been reported that roxithromycin in concentrations ranging from 0.1 to $10 \mu \mathrm{g} / \mathrm{ml}$ significantly enhances phagocytosis and killing of microorganisms by neutrophils ${ }^{17)}$ and monocytes ${ }^{18)}$. This could explain the good clinical results obtained in Chlamydia infections ${ }^{19)}$ since causative pathogens are intracellular microorganisms.

In conclusion, roxithromycin appears as a promising new macrolide endowed with potent in vivo antibacterial activity due to significantly improved pharmacokinetic properties. These have been confirmed in humans where the drug is well tolerated ${ }^{20 \sim 22)}$. Results obtained in early clinical trials with low daily doses of roxithromycin are very encouraging, and in good agreement with the above findings ${ }^{23)}$.

\section{References}

1) McGuire, J. M.; R. L. Bunch, R. C. Anderson, H. E. Boaz, E. H. Flynn, E. H. Powell \& J. W. Smith: Ilotycin, a new antibiotic. Antibiot. Chemother. 2: 281 283, 1952

2) Sobin, B. A.; A. R. English \& W. D. Celmer: P.A. 105, a new antibiotic. In Antibiotics Annual 19541955. Proc. Second. Ann. Symp. Antibiotics. Eds., H. Welch \& F. M.-IbañEz, pp. 827 830, Medical Encyclopedia, Inc., New York, 1954 1955

3) Pinnert-Sindico, S.; L. Ninet, J. Preud'Homme \& C. Cosar: A new antibiotic, spiramycin. In Antibiotics Annual 1954-1955. Proc. Second Ann. Symp. Antibiotics. Eds., H. WelCh \& F. M.-IbAÑEZ, pp. $724 \sim 727$, Medical Encyclopedia, Inc., New York, 1954 1955

4) Osono, T.; Y. OKa, S. Watanabe, Y. Numasaki, K. Moriyama, H. Ishida, K. Suzaki, Y. OKami \& H. Umezawa: A new antibiotic, josamycin. I. Isolation and physico-chemical characteristics. J. Antibiotics, Ser. A 20: 174 180, 1967

5) Bryskier, A. J.; J. C. Gasc \& J. F. Chantot: Classification and structure activity relationships of macrolides with emphasis on new developments. Abstracts of 14th Int. Congr. Chemother., WS-11-2, p. 53, Kyoto, June $23 \sim 28,1985$

6) Сhantot, J. F.; J. C. Gasc, S. Gouin D'Ambrieres \& A. Lutz: New ether oxime derivatives of erythromycin A: Preparation and antibacterial activities. Program and Abstract of the 23rd Intersci. Conf. Antimicrob. Agents Chemother., No. 447, Las Vegas, 1983

7) Jones, R. N.; A. L. BARry \& C. Thornsberry: In vitro evaluation of three new macrolide antimicrobial agents, RU 28965, RU 29065, RU 29702, and comparisons with other orally administered drugs. Antimicrob. Agents Chemother. 24: 209 215, 1983

8) Barlam, T. \& H. C. NeU: In vitro comparison of the activity of RU 28965, a new macrolide, with that of erythromycin against aerobic and anaerobic bacteria. Antimicrob. Agents Chemother. 25: 529 531, 1984 
9) Lorian, V. Ed.: Antibiotics in Laboratory Medicine. Williams \& Wilkins, Baltimore, 1980

10) Jones, R. N.: Recent developments and spectrum considerations among macrolide antimicrobics. Abstracts of 14th Int. Congr. Chemother., WS-11-12, p. 54, Kyoto, June 23 28, 1985

11) SAIto, A.: The activity of macrolides on organisms responsible for respiratory infections with emphasis on Legionella. Abstracts of 14th Int. Congr. Chemother., WS-11-7, p. 54, Kyoto, June 23 28, 1985

12) Ridgway, G. L.: The in vitro activity of macrolides against Chlamydia trachomatis and the genital Mycoplasmas. Abstracts of 14th Int. Congr. Chemother., WS-11-9, p. 54, Kyoto, June 23 28, 1985

13) BébéAR, C.; H. Renaudin, B. De Barbeyrac, P. CAntet \& C. Quentin: In vitro susceptibility of Ureaplasma urealyticum to RU 28965 compared to erythromycin and josamycin. Abstracts of 14th Int. Congr. Chemother., S-56-1, p. 208, Kyoto, June 23 28, 1985

14) Roussel-UCLAF: Data on file, 1983

15) Cevenini, R.; F. Rumpianesi, V. SAmbri \& M. LA Placa： In vitro activity of RU28965, a new macrolide, against Chlamydia trachomatis and Ureaplasma urealyticum. Abstracts of 14th Int. Congr. Chemother., P-46-80, p. 415, Kyoto, June $23 \sim 28,1985$

16) Chantot, J. F. \& A. Bryskier: Pharmacokinetic properties of the new macrolide RU 28965 in animals. Abstracts of 14th Int. Congr. Chemother., P-46-83, p. 416, Kyoto, June 23 28, 1985

17) Labro, M. T.; A. Bryskier \& C. Babin: Synergy between $\mathrm{RU}_{28065}$ and human neutrophils on bactericidal activity in vitro. Abstracts of 14th Int. Congr. Chemother., P-46-82, p. 416, Kyoto, June 23 28, 1985

18) Fietta, A.; P. Mangiarotti, C. Bersani, V. De Rose \& G. G. Grassi: In vitro effect of RU 28965 and other macrolide antibiotics on human neutrophil functions. Abstracts of 14th Int. Congr. Chemother., P-46-81, p. 415, Kyoto, June 23 28, 1985

19) Lassus, A.; A. Seppala, A. Eskelinen \& R. Hyodynmaa: A double-blind comparison of RU 28965, a new macrolide, and lymecycline in the treatment of non gonococcal urethritis. 6th Int. Meeting. Int. Soc. STD Res. (ISSTDR), Brighton, July Aug., 1985, in press

20) Tremblay, D.; A. J. Bryskier, M. Vuvkovic, A. Stockis \& C. Manuel: RU 28965, nouveau macrolide semi-synthétique. Biodisponibilité et profil pharmacocinétique aprés administration par voie orale. Pathol. Biol. 33: 502 506, 1985

21) Lassman, H. B.; S. K. Puri, I. Ho, R. Sabo \& A. Barry: Influence of food on the absorption of RU 965 (a new macrolide antibiotic) from film coated tablets in healthy men. Abstracts of 14th Int. Congr. Chemother., S-56-2, p. 208, Kyoto, June 23 28, 1985

22) Puri, S. K.; H. B. Lassman, I. Ho, R. Sabo \& A. Barry: Safety, tolerance, and pharmacokinetics of single and multiple oral doses of RU 965 (a macrolide antibiotic) in healthy men. Abstracts of 14th Int. Congr. Chemother., S-56-4, p. 209, Kyoto, June 23 28, 1985

23) Akoun, G.; A. Bertrand, I. Caubarrere, P. Constans, R. Dumont, P. Guibout, J. Kermarec, J. Marsac, M. Robillard, J. Sauvaget, P. Thibault, C. Voisin \& C. Safran: Clinical evaluation of RU 28965 in the treatment of hospitalized patients with lower respiratory tract infections (LRTI). Abstracts of 14th Int. Congr. Chemother., S-56-3, p. 208, Kyoto, June 23 28, 1985 